\title{
ANTICANCER EFFECTIVENESS OF VACCINATION BASED ON XENOGENEIC EMBRYO PROTEINS APPLIED IN DIFFERENT SCHEDULES
}

\author{
T.V.Symchych*, N.I. Fedosova, O.M. Karaman, L.M. Yevstratieva, H.S. Lisovenko, I.M. Voyeykova, H.P. Potebnia \\ R.E. Kavetsky Institute of Experimental Pathology, Oncology and Radiobiology, NAS of Ukraine, Kyiv 03022, Ukraine
}

The aim: To evaluate anticancer activity of vaccination with chicken embryo proteins (CEP) applied in different schedules. Materials and Methods: C57Bl mice were vaccinated with CEP before (prophylactic schedule) or after (different therapeutic schedules with or without preliminary tumor removal) the Lewis lung carcinoma cells transplantation. The latent period of tumor development, tumor volume and metastasis rate were evaluated. Results: Potent antimetastatic effect of CEP-based vaccination was seen in case of therapeutic regimen after primary tumor removal. The metastasis inhibition index (MII) reached 96.9 and $97.8 \%$ on $18^{\text {th }}$ and $34^{\text {th }}$ day after tumor removal, respectively. When CEP vaccination was performed in the settings of therapeutic regimen without primary tumor removal the anticancer effect was evident only if vaccinations started as early as $\mathbf{2 4} \mathrm{h}$ after the cancer cells injections. The highest MII achieved in such condition was $\mathbf{7 7 . 6 \%}$, tumor volume in the group of vaccinated animals was by $53.1-42.1 \%$ lower than in the control tumor-bearing mice. CEP vaccination before tumor challenge (prophylactic immunization) led to a statistically significant prolongation of the latent period of tumor development, a reduction of tumor volume (35.8-48.8\% compared to control unvaccinated mice) and a marked inhibition of metastasis (MII was 71.1\%). Conclusion: Vaccination based on CEP exhibited both prophylactic and therapeutic anticancer effects. The last one is more pronounced when the vaccination starts shortly after the primary tumor resection. Key Words: chicken embryo proteins, anticancer activity, Lewis lung carcinoma.

The development of xenogeneic anticancer vaccines (XAV) started at the end of the 1990s, when it was shown that the use of xenogeneic analogues of tumor associated antigens enables the body to overcome immunological toleration for its own proteins [1]. Now, it is proven that a number of tumor associated antigens and protein have their counterparts of animal or avian origin which can serve as antigens in XAV. These proteins or genes are exploited in the construction of XAVs, some of which have been shown to have anticancer effect $[2,3]$. Some XAV successfully passed I-II phases of clinical trials. Their safety and ability to induce immune response without autoimmune complications have been proven [4-8]. Among others, genes and proteins of chicken origin which share homology with human counterparts are exploited in the XAV construction [9-14].

At the R.E. Kavetsky Institute of Experimental Pathology, Oncology and Radiobiology (IEPOR) of the National Academy of Science of Ukraine XAV based on chicken embryo proteins (CEP) is under development. It is known that anticancer vaccines based on one or several antigens can lead to an immune editing of the tumor so that it loses antigens targeted by the vaccine. Moreover, polyantigenic vaccines potentially can elicit an immune response to a wider range of cancer antigens including unidentified ones [15]. That is why the vaccine which is being constructed is designed to be polyantigenic and is based on proteins extracted from the chicken embryo. In preliminary experiments,

Submitted: December 29, 2014.

*Correspondence: E-mail: symchychtv@gmail.com

Abbreviations used: CEP - chicken embryo proteins; ITGI - index of tumor growth inhibition; LLC - Lewis lung carcinoma; LLC$\mathrm{Ag}$ - Lewis lung carcinoma associated antigens; MII - metastasis inhibition index; XAV - xenogeneic anticancer vaccine. it was shown that blood serum of mice bearing different tumor strains has antibodies which react with CEP [16]. When injected to intact mice CEP caused no side effect or allergy reactions [17]. The aim of the current work is to evaluate the anticancer activity of CEP-based vaccine administered by different vaccination schedules.

\section{MATERIALS AND METHODS}

The study has been carried out on male $\mathrm{C} 57 \mathrm{BI} / 6$ mice 2-2.5 months old weighing $19-20 \mathrm{~g}$, bred in the IEPOR. The use and care of the experimental animals have been performed in accordance with the standard international rules of biologic ethics and was approved by Institutional Animal Care and Use Committee [18, 19]. The anticancer and antimetastatic efficacy of CEP was examined when vaccination was applied prior to tumor cells injection (prophylactic schedule), after tumor transplantation (therapeutic vaccination) or after tumor removal (post surgery vaccination). Lewis lung carcinoma (LLC) was used as the model of tumor growth.

CEP was prepared as follows [20]: 7 days chicken embryos were rinsed two times briefly in cold $0.9 \%$ $\mathrm{NaCl}$ solution, homogenized and then extracted with $0.9 \% \mathrm{NaCl}$ solution containing $0.1 \%$ EDTA, for $60 \mathrm{~min}$ at $4{ }^{\circ} \mathrm{C}$ by agitation. Following the extraction, chicken embryo tissue was removed by centrifugation at $1.500 \mathrm{~g}$ for $30 \mathrm{~min}$. The resulting supernatant was collected and frozen at $-20{ }^{\circ} \mathrm{C}$. Tumor associated antigens of LLC (LLC-Ag) were prepared by three consecutive cycles of freezing and melting of cell suspension. Following the last melting, cell debris was removed by centrifugation at $1.500 \mathrm{~g}$ for $30 \mathrm{~min}$. The resulting supernatants were collected and frozen at $-20^{\circ} \mathrm{C}$. The concentration of proteins in the extracts was measured by Greenberg and Craddock assay [21]. The same extracts were used in all the experiments described in the article. 
Irrespective of vaccination schedule, CEP or LLCAg immunizations were performed s.c. with $0.3 \mathrm{ml}$ solution per mouse (protein concentration $0.3 \mathrm{mg} / \mathrm{ml}$ ).

According to the prophylactic experiment, mice were immunized with CEP or LLC-Ag (three weekly injections); LLC cells were transplanted 30 days after the last immunization.

Therapeutic vaccination has been performed by three different schemes: on the $1^{\text {st }}, 8^{\text {th }}, 15^{\text {th }}$ days (group \#1); on the $7^{\text {th }}, 14^{\text {th }}, 28^{\text {th }}$ days after the tumor cell transplantation (group \#2); in the third group, vaccination started when the tumor nodule had become clearly palpable and was followed with two additional injections on the $3^{\text {rd }}$ and $10^{\text {th }}$ days after the first vaccination (that corresponds to the $12^{\text {th }}, 15^{\text {th }}$ and $22^{\text {nd }}$ days after the tumor transplantation).

Post surgery vaccination started on the $1^{\text {st }}, 8^{\text {th }}, 15^{\text {th }}$ days after the tumor removal, which corresponds to the $18^{\text {th }}, 24^{\text {th }}$ and $31^{\text {st }}$ days after tumor transplantation.

In the prophylactic and treatment vaccination experiments cancer cells suspension was injected i.m. into the right hind leg at a dose of $4 \times 10^{5}$ cells/mouse. Unvaccinated mice with the tumor were used as the control.

In the post surgery vaccination experiment, LLC cells were injected per foot at a dose of $2.5 \times 10^{5} \mathrm{cells} /$ mouse. The tumor removal was performed on the $17^{\text {th }}$ day after the tumor transplantation. Mice which have undergone surgical tumor removal but received no vaccination are referred as the control.

Tumor dimensions were measured with calipers, and tumor volumes were calculated according to the formula:

Tumor volume $=2 / 3 \pi \cdot$ width $^{2} \cdot$ length.

The Index of Tumor Growth Inhibition (ITGI) was calculated according to the formula:

$I T G I=100 \% \cdot\left(V_{\text {control mice }}-V_{\text {immunized mice }}\right) / V_{\text {control mice, }}$,

where $V_{\text {control mice }}$ and $V_{\text {immunized mice }}$ stand for the mean tumor volume in control and immunized mice respectively.

To assess metastasis burden mice were sacrificed and in each animal lungs were removed; surface lung metastases were counted and measured. The metastases volume was calculated as following:

$$
V=4 \pi r^{3} / 3 \text {, }
$$

where $r$ - stands for the metastases radius. The percentage of mice bearing metastases is referred as metastases rate. The mean number of metastases was calculated per all the mice in group and per mice bearing metastases.

Metastasis Inhibition Index (MII) was calculated as following:

$$
\text { MII }=100 \% \cdot\left(A_{c} \cdot B_{c}-A_{i} \cdot B_{i}\right) /\left(A_{c} \cdot B_{c}\right),
$$

where $A_{c}$ and $A_{i}$ stand for the number of mice bearing lung metastases in groups of control and immu- nized mice respectively. $B_{c}$ and $B_{i}$ stand for the mean number of lung metastases in groups of control and immunized mice respectively [22]. The results were analyzed for statistical significance by paired $t$-test using StatSoft STATISTICA 7.0. Values $p<0.05$ were considered as statistically significant $[23,24]$. The data in figures and tables are presented as $M \pm S D$.

\section{RESULTS}

The anticancer activity of CEP applied before tumor transplantation (prophylactic immunization). CEP or LLC-Ag were injected three times with one-week intervals. Then 30 days after the last immunization, LLC was transplanted into both unvaccinated animals (the control) and mice vaccinated with CEP or LLC-Ag. LLC tumor appeared in $81.0 \%$ ( 17 out of 21 ) of the control mice (Table 1). In the treatment groups, $77.8 \%$ ( 7 out of 9 ) and $81.8 \%$ ( 9 out of 11 ) of mice immunized with LLC-Ag or CEP, respectively, developed LLC tumors. The difference between all the groups was not significant. The latent period of tumor development was shorter $(p<0.05)$ in the group of the control mice (7.8 days) compared to the mice pre-vaccinated with LLC-Ag (10.0 days) or CEP (10.9 days).

Table 1. The latent period of tumor development and tumor transplantation efficacy in the vaccinated and control LLC-bearing mice

\begin{tabular}{lcc}
\hline Group & $\begin{array}{c}\text { Tumor transplantation } \\
\text { efficacy, \% }\end{array}$ & $\begin{array}{c}\text { Latent period of tumor } \\
\text { development, days }\end{array}$ \\
\hline Control & $81.0 \pm 13.1$ & $7.8 \pm 0.4$ \\
LLC-Ag & $77.8 \pm 13.9$ & $10.0 \pm 0.7^{\star}$ \\
CEP & $81.8 \pm 11.6$ & $10.9 \pm 0.6^{\star}$ \\
\hline
\end{tabular}

Note: $" \mathrm{p}<0.05$ compared to the control group.

The tumor growth kinetics is shown in Fig. 1. During the experiment, the smallest tumor volume was observed in the group of mice immunized with CEP ( $p<0.05$ compared to the control group). In the group of CEP-immunized mice, the ITGI reached 35.8-48.8\% depending on time after the tumor transplantation. The tumor volume of mice immunized with LLC-Ag did not differ significantly compared to both control and CEPimmunized mice. In the group of LLC-Ag-immunized mice, the maximal ITGI (28.4\%) was observed on the $14^{\text {th }}$ day after the tumor transplantation (Table 2).

On day 28 after LLC transplantation, all the mice of the control and treatment groups were euthanized so the metastases rate to be evaluated. The results are shown in Table 3.

In the mice vaccinated with CEP, $73.4 \%$ reduction of the mean metastasis volume was registered, in particular, 51.5 and $72.1 \%$ decrease of the metastases number per mouse or per mouse in the group correspondingly. So, in this group MII reached 59.5\% per metastases-bearing mouse and $71.1 \%$ per group. Contrary to CEP, LLC-Ag vaccination was not effective against metastases development.

\begin{tabular}{|c|c|c|c|c|c|c|c|}
\hline \multirow{2}{*}{ Group } & \multirow{2}{*}{ Parameter } & \multicolumn{6}{|c|}{ Days after LLC transplantation } \\
\hline & & 10 & 14 & 17 & 21 & 24 & 28 \\
\hline Control & Tumor volume, $\mathrm{mm}^{3}$ & $165.0 \pm 22.5$ & $493.7 \pm 62.2$ & $981.0 \pm 120.1$ & $1523.7 \pm 85.1$ & $2087.8 \pm 114.1$ & $2492.4 \pm 268.2$ \\
\hline LLC-Ag & $\begin{array}{l}\text { Tumor volume, } \mathrm{mm}^{3} \\
\text { ITGI, \% }\end{array}$ & $\begin{array}{c}163.5 \pm 35.8 \\
0.9\end{array}$ & $\begin{array}{c}353.6 \pm 65.0 \\
27.4\end{array}$ & $\begin{array}{c}856.6 \pm 125.0 \\
12.7\end{array}$ & $\begin{array}{c}1172.2 \pm 190.3 \\
23.1\end{array}$ & $\begin{array}{c}1550.9 \pm 291.2 \\
25.7\end{array}$ & $\begin{array}{c}1891.5 \pm 332.7 \\
24.1\end{array}$ \\
\hline CEP & $\begin{array}{l}\text { Tumor volume, } \mathrm{mm}^{3} \\
\text { ITGI, \% }\end{array}$ & $\begin{array}{c}84.6 \pm 8.3 \\
48.8\end{array}$ & $\begin{array}{c}301.5 \pm 54.6 \\
38.9\end{array}$ & $\begin{array}{c}512.8 \pm 73.0 \\
47.7\end{array}$ & $\begin{array}{c}892.3 \pm 132.0 \\
41.4\end{array}$ & $\begin{array}{c}1321.1 \pm 215.3 \\
36.7\end{array}$ & $\begin{array}{c}1600.8 \pm 246.7 \\
35.8\end{array}$ \\
\hline
\end{tabular}

Table 2. Tumor volume and ITGI in control and vaccinated before tumor transplantation mice bearing LLC 


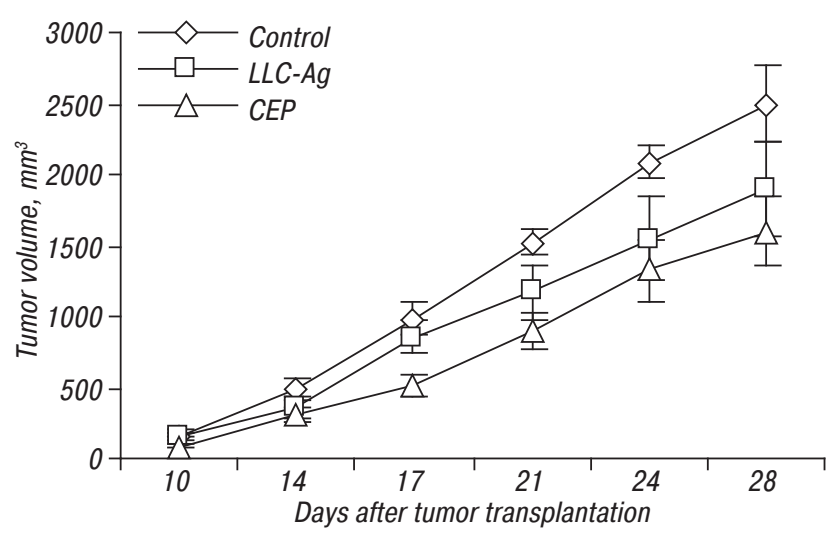

Fig. 1. The growth kinetics of LLC in control and pre-vaccinated animals

Table 3. Metastasis burden in control and vaccinated before tumor transplantation mice bearing LLC

\begin{tabular}{|c|c|c|c|c|}
\hline \multirow[b]{2}{*}{ Group } & \multirow[b]{2}{*}{$\begin{array}{c}\text { Metastases } \\
\text { rate, } \%\end{array}$} & \multirow[b]{2}{*}{$\begin{array}{l}\text { Volume } \\
\text { of metasta- } \\
\text { ses, } \mathrm{mm}^{3}\end{array}$} & \multicolumn{2}{|c|}{ Number of metastases } \\
\hline & & & $\begin{array}{l}\text { per mouse } \\
\text { bearing me- }\end{array}$ & per group \\
\hline$\overline{\text { Control }}$ & $70.0 \pm 14.5$ & $38.9 \pm 13.9$ & $20.6 \pm 6.5$ & $14.4 \pm 5.5$ \\
\hline LLC-Ag & $88.9 \pm 9.9$ & $30.4 \pm 10.3$ & $22.9 \pm 7.1$ & $22.9 \pm 7.1$ \\
\hline & $50.0 \pm 20.4$ & $10.4 \pm 3.0$ & $11.7 \pm 3.5$ & $5.8 \pm 3.2$ \\
\hline
\end{tabular}

The anticancer activity of the CEP-based vaccination applied after the tumor transplantation (therapeutic vaccination). Therapeutic vaccination with CEP has been performed according to three different schedules of vaccination (described in details in the Materials and Methods section). Any of immunization schedules appeared to be superior in transplantation efficacy and latent period of LLC development, as far as $85.9-89.6 \%$ of the vaccinated and control mice developed tumors on the $9-11^{\text {th }}$ day after the LLC cells transplantation.

When it comes to the tumor volume, the most evident effect on tumor growth was observed in the group of mice vaccinated according to the schedule\#1 (Fig. 2). Compared to the control group, the difference was significant $(p<0.05)$ till the $20^{\text {th }}$ day after the tumor challenge. The ITGI reached $53.13 \%$ on $14^{\text {th }}$ day after the LLC transplantation and was decreasing slowly till the $28^{\text {th }}$ day of the experiment. Although the ITGI $(42.1 \%)$ observed at this time point of the follow-up period (the $28^{\text {th }}$ day after the LLC transplantation) was the lowest for the group \#1, it remained to be the highest among the other groups. The tumor volume of the mice vaccinated according to the two other schedules did not differ significantly compared with the control group.

On day 28 after the tumor transplantation, all the mice were euthanized to assess the metastasis loading (Table. 4). The results of the group \#1 were out-standing. In this group, the lowest mean metastases number per group was recorded $(0.05<p<0.1$ compared to the control group). The mean metastases volume was by $54.4 \%$ lower than that in the control group. So, the MII in group \#1 reached $77.6 \%$ (per group) or $66.3 \%$ (per mice bearing metastases) and was the highest among all the treatment and control groups. In other treatment groups, the results did not differ significantly from that of the control group.

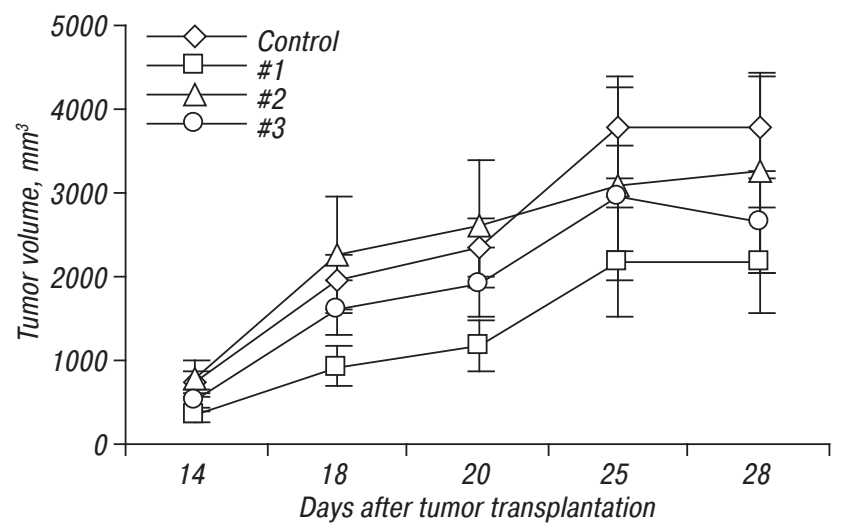

Fig. 2. The tumor growth kinetics in animals vaccinated with CEP and control mice

It is worth mentioning that only in the group \#1 all the mice were still alive till the end of the experiment (28 days after tumor transplantation). The worst survival rate was in the group \#3 (here the vaccination started after the tumor nodule could be palpable), in which $50 \%$ of immunized mice died before the experiment termination.

Table 4. Indexes of metastasis rate in animals vaccinated by different therapeutic schedules and in control LLC-bearing mice

\begin{tabular}{ccccc}
\hline \multirow{2}{*}{ Group } & $\begin{array}{c}\text { Metastases } \\
\text { rate, } \%\end{array}$ & $\begin{array}{c}\text { Volume } \\
\text { of metasta- } \\
\text { ses, } \mathrm{mm}^{3}\end{array}$ & $\begin{array}{c}\text { Number of metastases } \\
\text { bearing me- } \\
\text { tastases }\end{array}$ & per group \\
\hline Control & $85.7 \pm 12.4$ & $10.1 \pm 5.4$ & $10.4 \pm 3.4$ & $10.4 \pm 3.4$ \\
$\# 1$ & $66.7 \pm 19.2$ & $4.6 \pm 3.9$ & $4.5 \pm 2.0$ & $3.0 \pm 1.6^{\star}$ \\
$\# 2$ & $80.0 \pm 19.4$ & $31.3 \pm 15.7$ & $17.7 \pm 8.4$ & $13.2 \pm 7.6$ \\
$\# 3$ & $66.7 \pm 27.2$ & $13.2 \pm 6.2$ & $23.0 \pm 8.5$ & $15.3 \pm 10.3$ \\
\hline
\end{tabular}

Note: * $0.05<p<0.1$ compared to the control group.

The anticancer activity of CEP applied after the tumor resection (post surgical therapeutic vaccination). As far as the most prominent anticancer results were observed in the group of mice immunized on the $1^{\text {st }}, 7^{\text {th }}$ and $14^{\text {th }}$ days after tumor transplantation (group \#1), the same schedule was chosen to be applied in the study of post surgical therapeutic vaccination. Mice were transplantated with LLC cells (per foot); on the $17^{\text {th }}$ day after transplantation the tumor nodule was removed. All the mice were divided into two groups. The mice in the CEP group underwent vaccinations with CEP on the $1^{\text {st }}, 7^{\text {th }}$ and $14^{\text {th }}$ days after tumor resection. On the $35^{\text {th }}$ and $50^{\text {th }}$ days after the tumor transplantation (the $18^{\text {th }}$ and $34^{\text {th }}$ days after the tumor removal, respectively) the mice of both (control and treatment) groups were euthanized to assess the metastases burden (Table 5).

Table 5. Metastasis indexes in mice vaccinated with CEP after surgical removal of LLC

\begin{tabular}{|c|c|c|c|c|c|c|c|c|}
\hline \multirow{3}{*}{ Group } & \multicolumn{4}{|c|}{ The day 18 after tumor removal } & \multicolumn{4}{|c|}{ The day 34 after tumor removal } \\
\hline & \multirow[b]{2}{*}{$\begin{array}{c}\text { Metastases } \\
\text { rate, \% }\end{array}$} & \multirow{2}{*}{$\begin{array}{l}\text { Volume of me- } \\
\text { tastases, } \mathrm{mm}^{3}\end{array}$} & \multicolumn{2}{|c|}{ Number of metastases } & \multirow[b]{2}{*}{$\begin{array}{c}\text { Metastases } \\
\text { rate, } \%\end{array}$} & \multirow[b]{2}{*}{$\begin{array}{l}\text { Volume of me- } \\
\text { tastases, } \mathrm{mm}^{3}\end{array}$} & \multicolumn{2}{|c|}{ Number of metastases } \\
\hline & & & $\begin{array}{l}\text { per mouse be- } \\
\text { aring metastases }\end{array}$ & per group & & & $\begin{array}{l}\text { per mouse be- } \\
\text { aring metastases }\end{array}$ & roup \\
\hline Control & $72.7 \pm 13.4$ & $69.3 \pm 25.8$ & $16.5 \pm 3.6$ & $12.0 \pm 3.5$ & $66.7 \pm 13.6$ & $133.1 \pm 98.5$ & $4.2 \pm 2.0^{2}$ & $2.4 \pm 1.1^{2}$ \\
\hline CEP & $27.3 \pm 13.4^{1}$ & $1.2 \pm 0.9^{1}$ & $3.7 \pm 1.1^{1}$ & $1.0 \pm 0.6^{1}$ & $15.4 \pm 10.0^{1}$ & $0.8 \pm 0.4$ & $1.5 \pm 0.7$ & $0.2 \pm 0.2$ \\
\hline
\end{tabular}

Note: ${ }^{1} p<0.05$ compared to the control; ${ }^{2} p<0.05$ compared to the $18^{\text {th }}$ day after tumor removal. 
In this experimental setting, CEP showed evident and long-lasting antimetastatic effect. Independently on observation time, CEP immunization led to reduction of the metastases rate, metastases number and volume. For example, on the $18^{\text {th }}$ day after the tumor removal, only $27.3 \%$ of the immunized mice had metastases, while in the control group this index reached $72.7 \%$ (the difference was statistically significant). The metastases volume in the group of vaccinated mice was by $98.3 \%$ lower $(p<0.05)$ when compared to the control mice. The mean number of metastases per metastases-bearing mouse or per group in total was statistically significantly lower in the group of CEP vaccinated mice. So, MII reached $91.7 \%$ per mouse and $96.9 \%$ per group.

On the day $34^{\text {th }}$ after the tumor removal, mice in the control group showed disease progression. For example, the metastases volume increased by 1.92 times, compared with the $18^{\text {th }}$ day after the tumor removal. The mean number of metastases slightly decreased possibly due to the merging of small metastases. The metastasis rate did not change significantly $(66.7 \pm 13.6$ and $72.7 \pm 13.4 \%$ of control mice had metastases on the $34^{\text {th }}$ and $18^{\text {th }}$ days after the tumor removal respectively).

On the other hand, mice immunized with CEP showed stabilization of metastatic process. In particular, the metastases volume was $0.8 \pm 0.4 \mathrm{~mm}^{3}$ (to compare, it was $1.2 \pm 0.9 \mathrm{~mm}^{3}$ on the $18^{\text {th }}$ day after the tumor removal); the metastases number per mouse bearing it was $1.5 \pm 0.7\left(3.7 \pm 1.1\right.$ on the day $18^{\text {th }}$ of examination). In control mice, metastasis rate in the group of vaccinated mice did not differ significantly from the previous point of observation.

So, we can assume that on the $18^{\text {th }}$ day after the tumor removal almost all the mice (of both control and treatment groups) which were prone to develop metastases developed them, as long as the metastasis rate did not differ significantly on the $18^{\text {th }}$ and $34^{\text {th }}$ days of observation. But the metastasis rate was statistically lower in the CEP vaccinated group during all the experiment (i.e. on the $18^{\text {th }}$ and $34^{\text {th }}$ days after tumor removal) compared to the control. What is important, the vaccinated mice showed inhibition of metastases growth, whereas in the control group the mean metastases volume increased by almost 2 times. As a result, the mean metastases volume in the group of immunized mice was by $94.4 \%$ lower than that in the control group. In the CEP group, the MII calculated per group was equivalent to $97.8 \%$. So, the antimetastatic effect of CEP-based vaccination was observed for a prolonged period of time even after the termination of the vaccination.

\section{DISCUSSION}

So, as it was shown in the model of LLC, vaccination with CEP appears to have anticancer and antimetastatic effects. In the previous experiments it has been shown that there were CEP-specific antibodies in the blood serum of mice bearing different tumor strains (LLC, sarcoma 37, Ehrlich carcinoma, melanoma B-16) [16]. The presence of CEP-specific antibodies in the blood serum of unimmunized tumor-bearing mice may be explained by at least two reasons: polyspecific antibody circulation $[25,26]$ and the presence of some homologous proteins in CEP. It is known that some proteins of chicken origin share homology with mammals proteins, including that of human and mice $[9,10,12,27-29]$. The anticancer effect of CEP seems to be based on the last assumption. Especially, it looks possible when we consider the antitumor and antimetastatic effects of CEP applied before the tumor challenge - in so called prophylactic settings. According to the prophylactic schedule which was applied in the experiment, the tumor cell injection was performed on the $30^{\text {th }}$ day after the last immunization. Till the $30^{\text {th }}$ day after the CEP injection, the immune response induced by the immunization was expected to terminate [30], but immune memory cells had been already established [31]. The immune memory is capable of mounting a rapid response to subsequent antigen stimulation [32]. In the experiment, LLC cell suspension in the dose sufficient to induce tumors was used instead of the antigen re-challenge. Since a statistically significant prolongation of the latent period of tumor development in the groups of immunized mice was observed, it points to the generation of the rapid immune response to the cancer cells injection. That is, the mice immunized with CEP or LLC-Ag in the prophylactic mode mounted a rapid immune response to cancer cells as if it was an antigen re-challenge.

Subsequently, the observed results indicate with high probability that CEP contains some proteins which share homology with LLC antigens and immunization with CEP leads to immune memory formation. Moreover, in terms of its antimetastatic activity, vaccination with CEP was much more effective than application of LLC-Ag. This finding can be considered as an additional demonstration that xenogeneic homologous proteins are useful for breaking immune tolerance towards autologous cancer antigens.

In case of therapeutic immunization, the anticancer effect of CEP was evident only when applied at the very early stage of tumor formation ( $24 \mathrm{~h}$ after tumor cells injection, group \#1), when tumor burden is minimal. When vaccination was postponed to only 7 days (group \#2) the anticancer effect could hardly be observed. Furthermore, vaccination with CEP has no anticancer effect when applied to mice with the already established tumor (group \#3). So, it can be concluded that without prior tumor removal the application of anticancer vaccine based on CEP will have a minimal anticancer effect in clinical settings. On the other hand, it confirms a generally acknowledged statement that benefit of an anticancer vaccine is most evident when it is applied in earlier and less aggressive disease settings, that is in settings of minimal residual disease $[33,34]$.

Owning to this, the third experiment - application of CEP after the surgical resection of the tumor was conducted. In this case, CEP application had a pronounced and long-lasting antimetastatic effect. The number of metastases bearing mice and the mean 
metastases volume were significantly reduced in the group of treated mice. These effects were evident till the $34^{\text {th }}$ day after the tumor removal - the day of the experiment termination. It should be mentioned that the mean metastases volume in the CEP group was 60 and 168.5 times smaller than that of the control group on the $18^{\text {th }}$ and $34^{\text {th }}$ days after the tumor resection respectively. MII was very high and reached 96.9 and $97.8 \%$ per group in total on the $18^{\text {th }}$ and $34^{\text {th }}$ day respectively. It can be assumed that this vaccine when applied after the surgical removal of a tumor may dramatically improve therapeutic efficacy of cancer treatment, as long as metastatic spread of a tumor is the main death cause of cancer patients [35].

It has been shown that some genes or proteins of chicken origin, when used as a xenogeneic vaccine, can elicit anticancer effect or tumor specific immune response. For example, xenogeneic vaccines based on chicken HSP70 [11], MMP-2 [10, 14], Tie-2 [9] or FGFR $[12,13]$ were effective in case of $\operatorname{LLC}[10,14]$, fibrosarcoma Meth $\mathrm{A}[13,10]$, hepatoma $\mathrm{H} 22[9,10]$, melanoma B-16 [9], CT26 colon adenocarcinoma [14], canine cancer [11]. Anticancer effects of CEP are comparable with these of the vaccines mentioned above. Whether CEP contains some of abovementioned proteins or its anticancer effect is based on other antigens it remains to be elucidated.

\section{CONCLUSION}

Vaccination based on CEP exhibited both prophylactic and therapeutic anticancer effects. The last one is more pronounced when the vaccination starts shortly after the primary tumor resection. In this case, the MII reaches $91.7 \%$. So, CEP are suitable to be used in xenogeneic cancer vaccine construction.

\section{REFERENCES}

1. Naftzger $\mathrm{C}$, Takechi $\mathrm{Y}$, Kohda $\mathrm{H}$, et al. Immune response to a differentiation antigen induced by altered antigen: A study of tumor rejection and autoimmunity. Proc Natl Acad Sci USA 1996; 93: 14809-14.

2. Potebnya GP, Symchych TV, Lisovenko GS. Xenogenic cancer vaccines. Exp Oncol 2010; 32: 61-5.

3. Sioud M, Sorensen D. Generation of an effective antitumor immunity after immunization with xenogeneic antigens. Eur J Immunol 2003; 33: 38-45.

4. Seledtsov VI, Shishkov AA, Surovtseva MA, et al. Xenovaccinotherapy for melanoma. Eur J Dermatol 2006; 6: 655-61.

5. Seledtsov VI, Niza NA, Felde MA, et al. Xenovaccinotherapy for colorectal cancer. Biomed Pharmacother 2007; 61: $125-30$.

6. Yuan J, Ku GY, Gallardo HF, et al. Safety and immunogenicity of a human and mouse gp 100 DNA vaccine in a phase I trial of patients with melanoma. Cancer Immunity 2009; 9. 5 p.

7. Ginsberg BA, Gallardo HF, Rasalan TS, et al. Immunologic response to xenogeneic gp100 DNA in melanoma patients: comparison of particle-mediated epidermal delivery with intramuscular injection. Clin Cancer Res 2010; 16: 4057-65.

8. Eriksson F, Totterman T, Maltais AK, et al. DNA vaccine coding for the rhesus prostate specific antigen delivered by intradermal electroporation in patients with relapsed prostate cancer. Vaccine 2013; 31: 3843-8.
9. Luo Y, Wen YJ, Ding ZhY, et al. Immunotherapy of tumors with protein vaccine based on chicken homologous Tie-2. Clin Cancer Res 2006; 12: 1813-9.

10. Su J-M, Wei Y-Q, Tian L, et al. Active immunogene therapy of cancer with vaccine on the basis of chicken homologous matrix metalloproteinase-2. Cancer Res 2003; 63: 600-7.

11. Yu W-Y, Chuang T-F, Guichard C, et al. Chicken HSP70 DNA vaccine inhibits tumor growth in a canine cancer model. Vaccine 2011; 29: 3489-500.

12. Shaojiang Zh, Fengying H, Shaoping Zh, et al. Vaccination with a recombinant chicken FGFR-1 bypasses immunological tolerance against self-FGFR-1 in mice. J Huazhong Univ Sci Technolog Med Sci 2006; 26: 389-91.

13. Shaoping Zh, Junzhi Zh, Shaojiang Zh, et al. Antiangiogeneic target therapy for cancer with vaccine based on the recombinant chicken FGFR-1 in tumor-bearing mice. J Huazhong Univ Sci Technolog Med Sci 2007; 27: 120-3.

14. Yi T, Wei Y-Q, Tian L, et al. Humoral and cellular immunity induced by tumor cell vaccine based on the chicken xenogeneic homologous matrix metalloproteinase-2. Cancer Gene Therapy 2007; 14: 158-64.

15. Srinivasan R, Wolchok JD. Tumor antigens for cancer immunotherapy: therapeutic potential of xenogeneic DNA vaccines. J Transl Med 2004; 2. 12 p.

16. Symchych TV, Karaman OM, Voyeykova IM, et al. Experimental approaches to elaboration on the diagnostic test based on embryo proteins. Naukovi Zapysky NAUKMA 2010; 106: 29-32 (in Ukrainian).

17. Symchych TV, Karaman OM, Yudina OY, et al. Toxic and immunomodulating effects evaluation of chicken embryonic proteins on Balb/c mice. Naukovi Zapysky NAUKMA 2009; 93: 31-6 (in Ukrainian).

18. Kozhemyakin YM, Kchromov OS, Filonenko MA, et al. Scientific-practical recommendations on management of laboratory animals and work with them. Kyiv, 2002. 179 p. (in Ukrainian).

19. Council Directive 2010/63/EU of 22 september 2010 on the protection of animals used for scientific purposes. Official J Eur Commun 2010; 276: 33-79.

20. Isokawa $K$, Rezaee M, Wunsch A, et al. Identification of transferrin as one of multiple EDTA-extractable extracellular proteins involved in early chick heart morphogenesis. J Cell Biochem 1994; 54: 207-18.

21. Greenberg CS, Craddock P. Rapid single-step membrane protein assay. Clin Chem 1982; 28: 1725-6.

22. Cherdinceva NV, Kokorev OV, Konovalova NP, Kagiya VT. Enhancement of cytotoxic and cytostatic activities of spleen cells and macrophages by radiosensitizing drug AK-2123 in mice bearing Lewis lung carcinoma and treated with cyclophosphan. Exp Oncol 1997; 19: 333-7 (in Russian).

23. Lakin GF. Biometry. Moskow: Vyschaya Shkola, 1980. 290 p. (in Russian).

24. Sydenko AV, Vyshnyakov VV, Isaev SM. Theory of statistics. Manual. Moskow: MAKS-Press, 2011. 343 p. (in Russian).

25. Wing MG. The molecular basis for a polyspecific antibody. Editorial review. Clin Exp Immunol 1995; 99: 313-5.

26. Dimitrov JD, Pashov AD, Vassilev TL. Antibody polyspecificity: what does it matter? In: Lutz HU, eds. Naturally occurring antibodies (NAbs). New York: Springer Science+Business Media, 2012: 213-26.

27. Bassuk JA, Iruela-Arispe ML, Lane TF, et al. Molecular analysis of chicken embryo SPARC (osteonectin). Eur J Biochem 1993; 218: 117-27.

28. Schneider J, Linares R, Martinez-Arribas F, et al. Developing chick embryos express a protein which shares ho- 
mology with the nuclear pore complex protein Nup88 present in human tumors. Int J Dev Biol 2004; 48: 339-42.

29. Yamaguchi S, Iwata K, Shibuya M. Soluble Flt-1 (soluble VEGFR-1), a potent natural antiangiogenic molecule in mammals, is phylogenetically conserved in avians. Biochem Biophys Res Commun 2002; 291: 554-9.

30. Fahey JL, Sell S. The immunoglobulins of mice: the metabolic (catabolic) properties of five immunoglobulin classes. J Exp Med 1965; 122: 41-58.

31. Inamine A, Takahashi $Y$, Baba N, et al. Two waves of memory B-cell generation in the primary immune response. Int Immunol 2005; 17: 581-9.
32. Cellular and molecular immunology. In: Abbas AK, Lichtman AH, Pillai Sh, eds. Saunders Elsevier; $6^{\text {th }}$ ed, 2007: 215-42.

33. Bergman PJ. Anticancer vaccines. Vet Clin Small Anim 2007; 37: 1111-9.

34. Hale DF, Clifton GT, Sears AK, et al. Cancer vaccines: should we be targeting patients with less aggressive disease? Expert Rev Vaccines 2012; 11: 721-31.

35. Hart I. The spread of tumors. In: Knowles MA, Selby PJ, eds. Introduction to the cellular and molecular biology of cancer. $4^{\text {th }}$ ed. New York: Oxford University Press Inc, 2005: 278-88. 